\title{
Differences between Mathematics Representation Ability and Students' Self-Efficacy by Using Learning Cycle 7E and Discovery LearningBased on Batak Angkola Culture in SMAN 1 Sipirok
}

\author{
Azizah Yusra Amaliyah Harahap*, Edy Surya, Edi Syahputra \\ Graduate Program School in Mathematics Education, State University of Medan, Indonesia \\ *Corresponding author: ayusraharahap@gmail.com
}

Received October 04, 2018; Revised November 10, 2018; Accepted November 18, 2018

\begin{abstract}
The current study aims at: (1) analyzing differences between students' Mathematics presentation ability by using learningcycle7E and discovery learning based on BatakAngkola culture, (2) analyzing the differences between students' self-efficacy by using learningcycle7E and discovery learning based on BatakAngkola Culture, (3) finding out whether there is an interaction between the learning model and students' KAM on the Mathematics representation ability of students, and (4) discovering whether there is interaction between learning model and students KAM on students self-efficacy. The instruments used include: (1) test of representation ability, and (2) self-efficacy questionnaire. The data of the study is analyzed by using two ways variance analysis. The results of the study show that (1)there is difference in Mathematics representation ability of students who learn by using learningcycle7E model and those who learn by using discovery learning based on BatakAngkola Culture, (2) there is difference between self-efficacy of students who learn by using learning cycle 7E model and self-efficacy of students who learn by using discovery learning based on BatakAngkola Culture, (3) interactions exist between learning model and Students' KAM toward students' Mathematics representation ability, (4) interaction exist between learning model and Students' KAM toward student's self-efficacy.
\end{abstract}

Keywords: learning cycle 7E, discovery learning, matehmaticsrepresentation ability, self-efficacy

Cite This Article: Azizah Yusra Amaliyah Harahap, Edy Surya, and Edi Syahputra, "Differences between Mathematics Representation Ability and Students' Self-Efficacy by Using Learning Cycle 7E and Discovery LearningBased on Batak Angkola Culture in SMAN 1 Sipirok.” American Journal of Educational Research, vol. 6, no. 11 (2018): 1497-1504. doi: 10.12691/education-6-11-8.

\section{Introduction}

Hasratuddin (2015) proposes that students' mathematic representation ability becomes one of students' ability that needs to be concerned because it allows and helps students insolving math problems, transforming an abstract concept into concrete one, such as pictures, symbols, words, graphics, tables, etc. [1] Representation is one of higher order thinking ability aspects, the most important and fundamental component in developing students' thinking ability because in learning math, students are required to connect what they are learning and interpret the idea/concepts into various features.

According to Fadillah (Nursangaji, 2013), "representation is expressions of mathematical ideas presented by students as models or representatives in a math problem which are used problem solving they have as a result of students' thinking interpretation". [2] While Surya (2011) state that representation is a model or substitution of a problem to find the solving. [3] On the other hand, math experts who are the members of NCTM (2000) express that "students in the middle grades solve many problems in which they create and use representations to organize and record their thinking about mathematical ideas” [4].

According to Jones (Damanik, 2014), there are some factors why representation is important. First, it helps students to build a concept and mathematic thinking and to have ability and understanding of a strong and flexible concept established by teacher through mathematic representation. [5] Therefore, mathematic representation is essential for students to find out and build a means or thinking path in communicating mathematic construct from an abstract concept into a concrete one, so it is easily understood. In psychology, representation means a process of a concrete model in real life into an abstract model/ symbol (Hwang, 2007) [6].

Ozel and Yetkiner (2014) argue that there are two types of representation, they are (1) representation external is an old representation which represents a symbol. (2) Internal representation is a representation type which enables someone to create a concept and use that concept to master math. [7] 
Pape and Tchoshano (2001:120) claim that there are four notions demanded to use in understanding representation concepts, namely (1) representation is viewed as an internal abstraction of mathematical concept built by students through their experiences. (2) representation is known as a mental development from the previous mental state. (3) representation is a structured presentation of a picture, symbol, and sign analytically and geometric. (4) representation is a thinking tool to explain and clarify [8].

Huinker (2015) conveys that mathematic representation has 5 different model specifications, (1) visual representation describes events or works with Mathematic concepts using diagrams, pictures, lines, numbers, graphics, and any other math pictures. (2) Oral representation is a representation using language (words and phrases), interpreting, discussing, defining or describing mathematic ideas, and bridging formal and informal language. (3) Contextual representation is a representation which place mathematic ideas in daily, real words, or imaginary situation by using any discrete and continuous steps. (4) Physical representation it uses concrete things to show study act or manipulate mathematic ideas. (5) Symbolic representation is a work reports with mathematic ideas by using numbers variables, tables, and symbols.[9] Gagatsis, Christou and Elia (2004) propose that "student ability to understand mathematical concept depend on their ability to make translation among several models of representation".[10] It means that students have their own way to represent mathematic concept.

McCoy (Marpaung, 2016) state that in mathematics learning in the classroom, the representation should not be bound to change one form to another, in one way, but it could be two-way or even multiple ways. [11] According to Istiawati and Surya (2016) Indicator or operational form of representation ability is visual representation (diagram, table, graphic and picture), equations or mathematical expressions and written words or texts. [12] The application of correct representation will ease students to make mathematic concepts be more concrete. A complicated problem will be simpler if students are able to utilize an appropriate representation for the problem given, whereas a wrong construction of representation will make the problem be more difficult.

Besides having representation ability, another aspect needs to consider in math instructional process is affective aspect. Referring to taxonomy of Bloom, mathematical skills include cognitive, affective and psychomotor domains (Arikunto, 2012). [13] Therefore, other than cognitive aspect that is students' mathematic representation, the effect of affective aspect, psychological aspect related to students' self can be supporting factor of students success in learning process, especially in completing questions related to mathematic representation which require

Goldin (Gagatsis, 2009) states that affective skill is a complex system which consists of four main components; emotion, attitude, value and belief. [14] Octavia (2015) asserts that there is $70 \%$ relation between affective and cognitive competence. [15] So that it can be seen that the cognitive realm has a relationship with the affective domain. In this research, the researcher focuses on students' belief and attitude especially students' self efficacy. Skaalvik, Federici and Klassen (Sari, 2018) assert that the relations between student's grade and motivation were partly mediated through emotional support and self-efficacy. [16] This explanation is in line with mathematic instructional goal noted in KTSP, which is having attitude to appreciate the use of mathematic in real life, curiosity, attention, and interest in learning Mathematic, tenacity and confidence.

Hence, self-efficacy has to be developed by students in order to be able to interpret the process of learning mathematics in real life so the instructional process runs optimally and can help students to improve skill to solve mathematic problems. Amir and Risnawati (2016) contend that "self-efficacy is a positive attitude of an individual that enables him/her to develop positive choices both for him/her and environment/situation he/she faces". [17] According to Jerusalem dan Schwarzer (Masraroh, 2012) self-efficacy is someone's belief to finish his complicated problem or solve problem with all his effort”. [18]) According to Bandura (Habibah, 1994), self efficacy indicators consist of (1) Confidence to be able to solve own problem, (2) Confidence to be able to solve problems of others, (3) The ability to solve problems with the right solution. [19]

In reality, there are many students have lack self-efficacy in learning mathematic. This issue can affect the result of students' representation ability. This case is in line with what the researcher found at SMAN1 Sipirok. Based on the preliminary observation, it was found that students' mathematic representation and self-efficacy were low. Rahmawati (Hanifah, 2015) reveals that there are small number of students who are able to answer correctly the question related to representation ability, while some other students are not able to exploit their representation skill, especially visual representation. [20] Hudiono (Hutagaol, 2013) also said that students who worked on mathematical questions related to the ability of representation, only a small percentage of students could answer correctly, and most of the others were weak in utilizing their representation abilities, especially visual representation [21].

The impact of low self-confidence of students can influence their perspective on Mathematic, as expressed by Zakaria, Chung and Yusuf (2010: 272) in their research, students who are poor in Mathematic will feel less confident and do not want to choose science as a major to continue their education. [22] In addition, students' representation skill is influenced by students' self confidence, as stated by Furthermore the representation ability of students influenced by self-confidence was also conveyed by Gagatsis, Panaoura, Deliyianni and Elia (2009) Their research showed that high school students have less positive beliefs in using representation in learning mathematic than elementary school students. [23] Furthermore Russefendi (Arcat, 2013) expresses that after learning mathematic, there were some people who could not understand even simple Mathematic concept, and there were many concepts which were misunderstood. [24] Math is considered as a complicated and difficult field of study. The assumption that mathematics is difficult still implies that students' self-efficacy is still low.

Math instructional in 2013 Curriculum emphasizes on modern pedagogic dimension; by using scientific approach including observing, questioning, associating, experimenting, networking for all subjects learned(Permendikbud RI No. 65 Tahun 2013). [25]). Moreover, in 2013 Curriculum 
students are encouraged to check new information with their background knowledge (Permendikbud RI No. 81A Tahun 2013). [26] Yet, in reality the most instructional approach used by teachers is teacher-centered approach and traditional approach. This is in line with Wasriono, Syahputra and Surya (2015) They convey that mathematics instructional process is still centered on the teacher as the only source of knowledge, the teachers tend to use the expository method in the form of lectures, giving examples and exercises so that these processes will limit students' thinking ability in finding concepts, and using procedures required by students in solving mathematical problems [27].

Juliana and Surya (2017) express that selection of learning strategies and learning method is a solution to gain learning success. [28] It needs the right process and the right way so that the learning can be understood by students, one of which is creating effective learning. According to Yuniara and Surya (2017) the selection of learning strategies and choosing a learning model is one solution to achieving learning success. [29]

A solution to get learning success is by applying constructivism approach. Syamanski (Cahyo, 2013) delivers that instructional process in constructivist view is an active activity in which students construct their own knowledge.[30] Learning cycle is one of the learning models which uses a constructivism paradigm. Ergin, Kanli and Unsal (2008) state that "Learning Cycle model is a constructivist which provides learning a new concept or comprehension deeply a known concept” [31].

Learning cycle model was firstly developed by Atkin and Karplus. This learning model has been developed to be some divisions; they are three cycles, four cycles, five cycles, six cycles and seven cycles. Einskraft renewed 5E Cycle learning model by proposing learning cycle 7E model, by adding the changes to fix instructional process concepts. According to Yenilmez (Rosalina, Sutawidjaja and Sudirman, 2016) Learning cycle model creates specific opportunity for teachers to set students' thinking level development and to evaluate their learning level. [32]). 7E learning cycle stresses on checking out students' background knowledge before learning new content. The seven stages consist of elicit, engage, explore, explain, elaborate, extended, dan evaluate.

7E learning cycle model came from social constructivism of Vygotsky and Ausubel's meaningful learning theory. Baharuddin (2007) asserts that Vygotsky's theory of social constructivism is "social interaction plays an important role in the intellectual development of students". [33] This shows that in learning cycle 7E model emphasizes more on social nature in learning and suggests the use of learning groups which consist of different level of students abilities so that there will be interaction between studentstudent and students-teacher.

Tran (2014) "in the 21st century, the creation is one of crucial factors of the process of theaching and learning, teacher ussually uses a familiar method being discovery learning this method proves the activity of students”. [34] One of the student-centered instructional methods is by using discovery method. Bruner (Adhar, 2012) considers that discovery learning method is in line with active knowledge seeking done by human. [35] The discovery in this state is that students find a concept through teacher's guidance and direction because generally most of students need basic concepts to be able to find something. One of models which is appropriate is discovery learning.

Casad (2012) argues that discovery approach is a process in which students are pushed to rediscover, to try to give knowledge through his/her own discoveries and others. [36] According to Adelia and Surya (2017) in applying discovery learning, teaching learning activities are designed well so that students can come across concepts and principles through their own mental processes. [37] This statement is in line with the opinion of Herman (Silalahi, 2015) he proposes that Discovery Learning is a model for developing the way students actively find themselves and investigate themselves, so the results obtained will last long in memory and will not be easily forgotten by students. [38] Joyce \& Weil (Nurul, 2016), convey that discovery learning can help students to develop intellectual discipline skills needed to increase students' curiosity and answer their curiosity.[39]

The implementation of discovery learning is expected to be able to solve students' problem in learning mathematic so students are able to develop their representation ability and self efficacy by discovering their own solving in daily life. Local culture used in learning cycle 7E and discovery learning of this study is Batak Angkola culture. Mathematic Learning process which uses culture is known as ethnomatematic.

According to Shirley as how it is quoted by Hartoyo (2012), ethnomatematic field is Mathematic that arises and develops in society and is based on local culture it is a learning process and learning method. [40] Jones (Rizka, 2014), contends that ethnomatematic is a multicultural mathematic activity using culture to make a connection with a specific mathematical topic can motivate variety of students' culture and ethnic to find out and obtain respect for their own heritage culture while learning significant mathematical content. [41] One factor which allows ethnomathematic becomes a concern and interesting studies lately is because the teaching of mathematic in schools is too formal. Hiebert \& Capenter (Abdullah, 2016) add that teaching of mathematic at school and mathematic found by students in reality are very distinct. [42]

Teaching of mathematic at school has to be established in accordance with students' cultural background. A math teacher has significant roles in transforming cultural-based mathematic. Thus, learning mathematic is welcomed easier, close to the daily life of students, and it is not considered as a new subject that is far from real life. Cultural diversity in Indonesia is an issue which cannot be denied. It can be said that Indonesia is a country with a level of cultural diversity. Indonesia does not only have cultural diversity of ethnic groups, but also cultural diversity in the context of civilization, traditional to modern, and territorial.

One of Indonesian cultures is Batak Angkola culture. Batak Angkola-based instructional focuses on creating dynamic learning environment by showing relevance among mathematic concepts and culture which can be seen at concrete things, such as customs, languages, tribes, society habits, art, tourisms, etc. the relevance among mathematic concepts and Batak Angkolaculture can be known from people's habit and real objects, for the example life behavior pattern of people in their tribe, custom, language, living equipment, social organization, religion, art, etc. 


\section{Research Methods}

The current study aims at finding out the differences in students' Mathematic representation abilities and self-efficacy through the use learning cycle 7E model and discovery learning model basedon Batak Angkola culture in class X SMAN 1 Sipirok. This research is a kind of quasi experiment research

\subsection{Instrument and Data Collection Method}

To be able to collect completed, correct and thorough data and information related to what are discussed in this study, a set of research instrument is designed; that is a test of mathematic representation ability and self-efficacy questionnaire.

\subsubsection{Test of Mathematics Pleminary Ability}

Test of preliminary ability is organized to discover students' level in mathematic low, intermediate and advance, before instructional process is conducted and then the increasing of students' preliminary ability is observed.

\subsubsection{Test of Mathematics Representation Ability}

This kind of test is designed to know the difference in students' mathematic representation ability after that a treatment is given to students. Instrument of mathematic representation ability is developed from teaching material of Trigonometry chapter.

\subsubsection{Self-Efficacy Questionnaire}

The use of students' self-efficacy questionnaire aims to understand how students' self-efficacy is. Scale model used is Likert scale model. Likert scale is mostly used to measure someone or group attitude, idea, and perception concerning a social phenomena.

\section{Result and Discussion}

\subsection{Result Study}

\subsubsection{Normality and Homogenity}

The following is the summary of calculation result of normality test from post test of students' mathematic representation ability in the Table 1.

Table 1. Result of Normality Test-Post Test

\begin{tabular}{|c|c|c|c|}
\hline \multicolumn{4}{|c|}{ One-Sample Kolmogorov-Smirnov Test } \\
\hline & & LC7E & DL \\
\hline \multicolumn{2}{|l|}{$\mathrm{N}$} & 30 & 30 \\
\hline \multirow{2}{*}{ Normal Parameters $^{\mathrm{a}}$} & Mean & 80.30 & 74.83 \\
\hline & Std. Deviation & 5.694 & 4.602 \\
\hline \multirow{3}{*}{ Most Extreme Differences } & Absolute & .162 & .181 \\
\hline & Positive & .154 & .131 \\
\hline & Negative & -.162 & -.181 \\
\hline \multicolumn{2}{|l|}{ Kolmogorov-Smirnov Z } & .888 & .992 \\
\hline \multicolumn{2}{|l|}{ Asymp. Sig. (2-tailed) } & .410 & .279 \\
\hline
\end{tabular}

a. Test distribution is Normal.
Based on Table 1 it can be seen that significance values are 0.410 for experiment I and 0.279 for experiment II. Significance number for those two classes is higher than 0.05 so $\mathrm{H} 0$ which states that data is normally distributed for experiment class I and experiment class II is accepted. In other words, post-test data for experiment class I which is taught by using learning cycle 7E model and experiment class II by using discovery learning-based BatakAngkola culture have normally distributed data.

The result of Homogeneity is shown in the Table 2

Table 2. The Result of Homogeneity Test for Post-Test Ability

\begin{tabular}{|l|c|c|c|}
\hline \multicolumn{2}{|l|}{ Test of Homogeneity of Variances } \\
\hline POSTTEST & df1 & df2 & Sig. \\
\hline Levene Statistic & 1 & 58 & .108 \\
\hline 2.663 &
\end{tabular}

Table 2 shows that significance number 0.108 is higher than significance number of 0.05 so $\mathrm{H} 0$ which shows there is no difference in variance between two groups can be acceptable. This indicates that two groups of posttest data in the experimental class I which is taught by using learning cycle 7E and experimental class II which is taught by discovery learning model, based on Angkola Batak culture have homogeneous data variance.

Table 3 presents summary of Normality test result of students' self efficacy.

Table 3. Result of Normality Test for Post-Test Data of Students' Self-Efficacy

\begin{tabular}{|l|l|c|c|}
\hline \multicolumn{2}{|l|}{ One-Sample Kolmogorov-Smirnov Test } \\
\hline \multirow{2}{*}{$\mathrm{N}$} & & LC7E & DL \\
\hline \multirow{3}{*}{ Normal Parameters ${ }^{\mathrm{a}}$} & Mean & 30 & 30 \\
\cline { 2 - 4 } & Std. Deviation & 82.40 & 79.03 \\
\hline \multirow{3}{*}{ Most Extreme Differences } & Absolute & .214 & .147 \\
\cline { 2 - 4 } & Positive & .169 & .147 \\
\cline { 2 - 4 } & Negative & -.214 & -.119 \\
\hline Kolmogorov-Smirnov Z & & 1.174 & .804 \\
\hline Asymp. Sig. (2-tailed) & & .127 & .538 \\
\hline
\end{tabular}

a. Test distribution is Normal.

Based on Table 1 it can be seen that significance values are 0.127 for experiment I and 0.538 for experiment II. Significance number for those two classes is higher than 0.05 so $\mathrm{H}_{0}$ which states that data is normally distributefor experiment class I and experiment class II is accepted. In other words, post-test data for experiment class I which is taught by using learning cycle 7E model and experiment class II by using discovery learning-based BatakAngkola culture have normally distributed data

Hasil perhitungan homogenitas data postest SelfEfficacy ditampilkan pada Table 4.

Tabel 4. Hasil Uji Homogenitas Post-Test Self-Efficacy Siswa

\begin{tabular}{|l|c|c|c|}
\hline \multicolumn{2}{|l|}{ Test of Homogeneity of Variances } \\
\hline Skor Self-Efficacy & df1 & df2 & Sig. \\
\hline Levene Statistic & 1 & 58 & .253 \\
\hline 1.331
\end{tabular}


The Table 4 above proves that 0.253 significance number is bigger than 0.05 of significance level so $\mathrm{H} 0$ which states that there is no difference in variance between two groups is acceptable. It indicates that two group of Post-test data in experiment class I which is taught by learning cycle 7E and experiment class II which is taught by discovery learning model based on Batak Angkola culture have homogeneous data variance.

\subsection{Hipotesys Testing}

The results of the first and third hypothesis testing with the two-way ANAVA test using the SPSS Program are described in Table 5.

Based on Table 5 it can be seen that 0.000 significance value for model (sig. 0.05), it means that there is significant difference between average of students Mathematic representation ability in class which is taught by using learning cycle $7 \mathrm{E}$ and the class which is taught by using discovery learning, as a result, $\mathrm{HO}$ is rejected and $\mathrm{Ha}$ is accepted. This statement expresses that there is there are differences in Mathematic representation abilities of students who learn by using 7E learning cycle with those who learn by using discovery learning based on Batak Angkola culture.

In significance for model KAM line 0.000 significance value (sig. <0.05), so H0 is rejected and Ha is accepted. This shows that there is interaction between instructional models (learning cycle 7E and discovery learning) based on Batak Angkola with students' KAM toward students' Mathematic representation ability. This can be described in Figure 1.

Table 5. Hypothesis Testing of 1 and 3 with Two ways ANAVA

\begin{tabular}{|c|c|c|c|c|c|}
\hline \multicolumn{6}{|c|}{ Tests of Between-Subjects Effects } \\
\hline \multicolumn{2}{|c|}{ Dependent Variable:KRM } & \multirow[b]{2}{*}{ df } & \multirow[b]{2}{*}{ Mean Square } & \multirow[b]{2}{*}{$\mathrm{F}$} & \multirow[b]{2}{*}{ Sig. } \\
\hline Source & Type III Sum of Squares & & & & \\
\hline Corrected Model & $965.485^{\mathrm{a}}$ & 5 & 193.097 & 10.053 & .000 \\
\hline Intercept & 243666.601 & 1 & 243666.601 & $1.269 \mathrm{E} 4$ & .000 \\
\hline KAM & 2.159 & 2 & 1.079 & .056 & .945 \\
\hline MODEL & 293.946 & 1 & 293.946 & 15.303 & .000 \\
\hline KAM * MODEL & 500.481 & 2 & 250.240 & 13.028 & .000 \\
\hline Error & 1037.248 & 54 & 19.208 & & \\
\hline Total & 362998.000 & 60 & & & \\
\hline Corrected Total & 2002.733 & 59 & & & \\
\hline
\end{tabular}

a. R Squared $=, 482$ (Adjusted R Squared $=, 434$ ).

\section{Estimated Marginal Means of KRM}

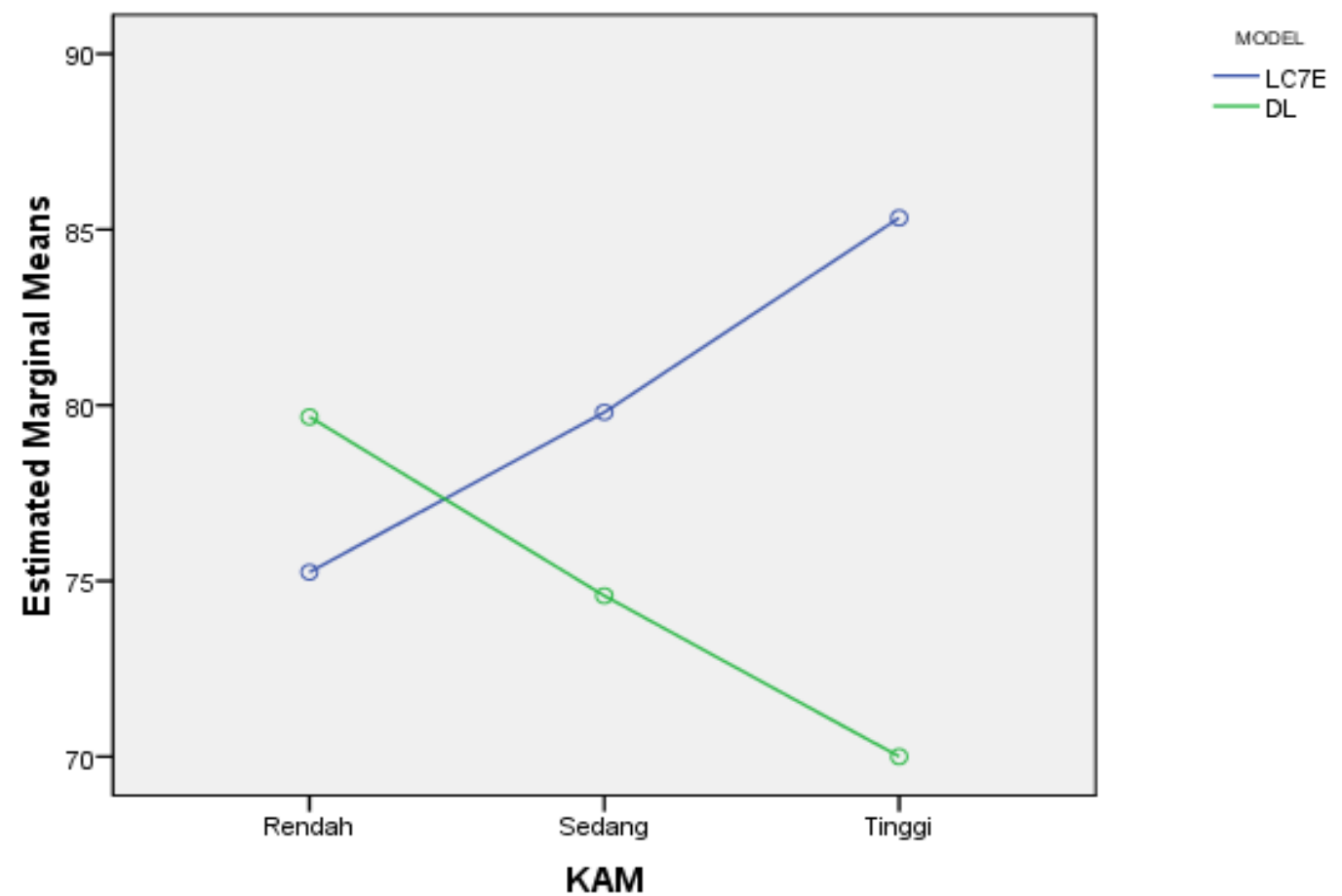

Figure 1. The Interaction Between Model Learning and KAM to Students MathematicsRepresentation ability 
From Figure 1, it is shown that the average score of students' mathematical representation ability in the low KAM category in the 7E learning cycle model is lower than the low KAM category in the discovery learning class. Whereas in the medium and high category of KAM, the average score of the ability of mathematical representation in the 7E learning cycle class is higher than the discovery learning class. So that there is an interaction between the learning model (learning cycle $7 E$ and discovery learning) and student's KAM to students' mathematical representation abilities. This means that there is a joint effect contributed by the learning model and Mathematics pleminary ability students on the students' mathematical representation abilities.

The results of the second and fourth hypothesis tests with the two-way ANAVA test using the SPSS Program are described in Table 6 .

Based on Table 6, significance value for model is 0.034 (sig. <0.05). This indicates that there is significant difference in average of self efficacy of students who learn by using $7 \mathrm{E}$ learning cycle with those who learn by using discovery learning based on Batak Angkola culture therefore $\mathrm{HO}$ is rejected and Ha is accepted. This case signifies that there is difference of self efficacy of students who learn by using learning cycle 7E with those who learn by using discovery learning -based Batak Angkola culture.

At significance for KAM * model is 0,000 (sig. <0.05), so $\mathrm{HO}$ is rejected and $\mathrm{Ha}$ is accepted. This shows that there is interaction between learning models (learning cycle 7E and discovery learning) based on Angkola Batak culture with KAM students towards self-efficacy. This can be described in Figure 2.

Table 6. Hypothesis Testing 2 and 4 with Two Ways ANAVA

\begin{tabular}{|c|c|c|c|c|c|}
\hline \multicolumn{6}{|c|}{ Tests of Between-Subjects Effects } \\
\hline \multicolumn{2}{|c|}{ Dependent Variable:SELFEFFICACY } & & & & \\
\hline Source & Type III Sum of Squares & Df & Mean Square & $\mathrm{F}$ & Sig. \\
\hline Corrected Model & $584.682^{\mathrm{a}}$ & 5 & 116.936 & 8.092 & .000 \\
\hline Intercept & 262648.173 & 1 & 262648.173 & $1.818 \mathrm{E} 4$ & .000 \\
\hline KAM & 156.361 & 2 & 78.180 & 5.410 & .007 \\
\hline MODEL & 68.316 & 1 & 68.316 & 4.728 & .034 \\
\hline KAM * MODEL & 274.925 & 2 & 137.462 & 9.513 & .000 \\
\hline Error & 780.301 & 54 & 14.450 & & \\
\hline Total & 391953.000 & 60 & & & \\
\hline Corrected Total & 1364.983 & 59 & & & \\
\hline
\end{tabular}

a. $\mathrm{R}$ Squared $=, 428$ (Adjusted R Squared $=, 375)$.

\section{Estimated Marginal Means of SELFEFFICACY}

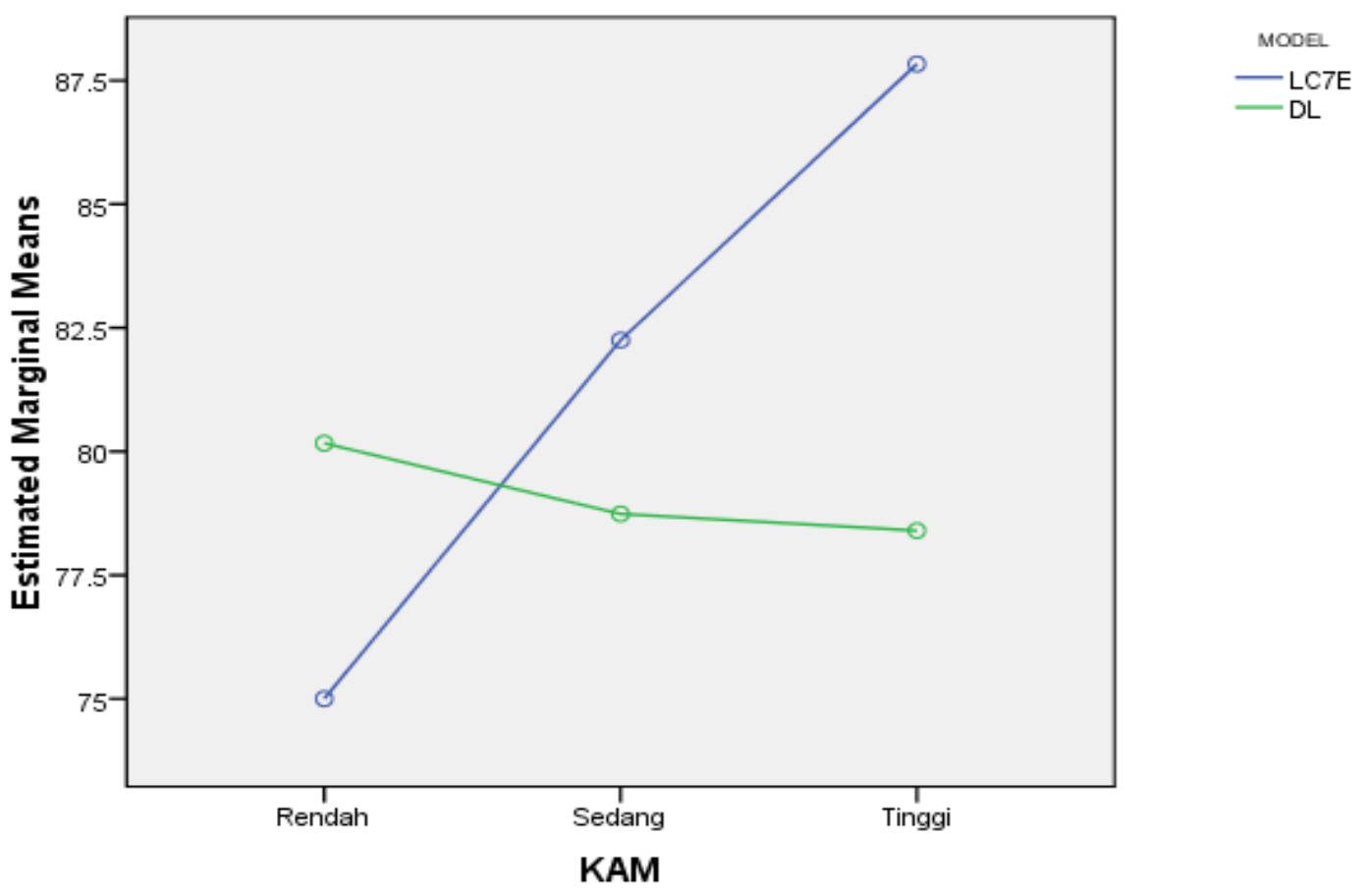

Figure 2. The Interaction Between Model Learning and KAM to Students Self-Efficacy 
From Figure 2 it is shown that the average score of the self-efficacy of students in the low KAM category in the 7E learning cycle model is lower than the low KAM category in the discovery learning class. Whereas in the medium and high category of KAM, the average score of student efficacy in the 7E learning cycle class is higher than the discovery learning class. So that there is an interaction between the learning model (7E learning cycle and discovery learning) and KAM students towards student self-efficacy. This means that there is a joint effect contributed by the learning model and KAM of students towards student self-efficacy.

\section{Conclusion}

Based on analysis result of data about Mathematic representation ability and self efficacy of students who learn by using learning cycle $7 \mathrm{E}$ and those who learn by using discovery learning-based Batak Angkola culture, it can be concluded that:

1. There is difference of Mathematic representation ability of students who learn by using learning cycle $7 \mathrm{E}$ and those who learn by using discovery learning- based Batak Angkola culture

2. There is difference of self-efficacy of students who learn by using learning cycle 7E and those who learn by using discovery learning- based Batak Angkola culture

3. There is interaction between learning model and KAM toward students' Mathematic representation ability. It can be interpreted that the interaction between learning models (learning cycle 7E and discovery learning) and KAM gives a significant influence on the students' mathematical representation abilities.

4. There is interaction between learning model and KAM toward students' self-efficacy. It means that the interaction between learning models (learning cycle 7E and discovery learning) and KAM gives a significant influence on the students' students' selfefficacy.

\section{Suggestion}

Based on the conclusion above, the researcher can give the following suggestions, they are:

1. Based on Research Findings

Based on research findings, it is expected that teachers can give better understanding to students in comprehending Mathematic problem and in representing Mathematic problem, especially for visual representation indicators and Mathematical equation.

2. For Math Teachers

Instructional process by using discovery learning should be an alternative in a teaching and learning process to maximize students' representation ability particularly for students with low KAM and selfefficacy, while learning cycle 7E can be an alternative for students who have intermediate and higher KAM and self-efficacy.
3. For Another Researchers

a. Subsequent researchers should conduct further research with more samples and include several schools in several regions with different cultures.

b. The next researcher should examine other related variables such as problem solving, reasoning and communication, Mathematical connections, Mathematical communication, quality of learning, student responses, etc

c. Researchers should design instructional tools and research instruments which are more effective and efficient by paying attention to the characteristics of learning approach or model applied in the classroom

4. For Related Institutions/Parties

Related institution should conduct socializations, trainings, and development of model or instructional approach so that it can be well recognized by all teaching staff and education personnel in order to improve students' Mathematic representation and self-efficacy

\section{References}

[1] Hasratuddin. 2015. Mengapa Harus Belajar Matematika?. Medan: Perdana Publishing.

[2] Nursangaji, A., Aryanti, D dan Zubaidah. 2013. Kemampuan Representasi Matematis Menurut Tingkat Kemampuan Siswa Pada Materi Segi Empat di SMP. Jurnal. Untan.Ac.id. Index.

[3] Zulfachri. F. M. R., Surya, Edi. 2017. Kemampuan Representase dalam Pembelajaran Matematika untuk Membangun Karakter Bangsa. Researchgate.

[4] NCTM. 2000. Principles and Standards for School Mathematics. NCTM: Reston VA.

[5] Damanik. 2014. Pengaruh Pembelajaran Berbasis Masalah terhadap Kemampuan Representasi dan Minat Belajar Matematika Siswa SMK Negeri 11 Medan. Tesis. Medan: tidak diterbitkan.

[6] Hwang, W.Y., Chen, N.S., Dung, J.J, \& Yang, Y.L. 2007. Multiple Representation Skills and Creativity Effects on Mathematical Problem Solving using a Multimedia Whiteboard System. Educational Technology \& Society. Vol. 10. No. 2. Hal: 191-212.

[7] Ozel, S., Capraro, R.M., \& Yetkiner, E.Z. 2014. A Thecnology Intervention Using Multiple Representations on Mathematics. Educational Technology \&society. Vol 10. number 2. hal: 19-212.

[8] Pape dan Tchoshanov. 2001. The role of representations in developing mathemathical understanding. Theory into practice. Vol. 40. No.2. hal: 118-127.

[9] Huinker, D. 2015. Representational Competence: A Renewed Focus For Classroom Practice in Mathematic. Center For Mathematics and Science Education Research, Canada: University of wisconsin Milwaukee. Text Book.

[10] Gagatsis, A. Panoura, A. Dan Elia, I. 2009. Students' Beliefs About The Use Of Representations In The Learning Of Fractions University of Cyprus: Federick University.

[11] Marpaung, R.I.T dan Syahputra, E (2016). Students' Matehematics Representation And The Alternative Solution. Proceeding of the $1^{\text {st }}$ Annual International Seminar on Transformative Education and Educational Leadership (AISTEEL). Vol. I hal. 260-266.

[12] Istiawati, S.N. Syahputra, E. Surya, E dan Saragih, S. 2017. The Analysis of Students' Representation Ability in Finishing Recital Question Assemblage Material in VII Grade Students of YPI Dharma Budi Junior High School. International Journal of Novel Research in Education and Learning. 2394-9686. Vol. 4. Issue 2. Hal: $111-117$.

[13] Arikunto, S. 2012. Dasar-dasar Evaluasi Pendidikan Edisi 2. Jakarta: Bumi Aksara. 
[14] Gagatsis, A. Panoura, A. Dan Elia, I. 2009. Students' Beliefs About The Use Of Representations In The Learning Of Fractions University of Cyprus: Federick University.

[15] Octavia, F. 2015. Analisis Kemampuan Siswa Kelas X pada Ranah Kognitif, Afektif dan Psikomotorik. OMEGA Jurnal Fisika dan Pendidikan Fisika. Vol. 1. No. 2. Hal: 24-29.

[16] Sari, D.P. Syahputra , E dan Surya, E. 2018. An Analysis Of Spatial Ability And Self-Efficacy Of Students In Cooperative Learning By Using Jigsaw At Smas Muhammadiyah 8 Kisaran. American Jurnal of Education Research. Vol. no. 8. Hal. 12381244.

[17] Amir, Z dan Risnawati. 2016. Psikologi Pembelajaran Matematika. Yogyakarta: Aswaja Pressindo.

[18] Masraroh, Latifatul. 2012. Efektivitas Bimbingan Kelompok Teknik Modeling Untuk Meningkatkan Self Efficacy Akademik Siswa (Studi Eksperimen Kuasi Di Kelas X Sekolah Menengah Atas Laboratorium Universitas Pendidikan Indonesia). Bandung: Universitas Pendidikan Indonesia.

[19] Habibah, L. Penerapan Pembelajaran Kooperatif Tipe STAD Berbantuan Software Autograph Untuk Meningkatkan Kemampuan Komunikasi Dan Self Efficacy Siswa Di SMP Kota Padang Sidempuan. Tesis. Medan: PPs UNIMED.

[20] Hanifah. 2015. Penerapan Pembelajaran Model Eliciting Activities (MEA) dengan Pendekatan Saintifik untuk Meningkatkan kemampuan Represetasi Matematis Siswa. Kreano Jurnal Matematika Kreatif-Inovatif. Vol. 6. No. 2. Hal: 191-198.

[21] Hutagaol, K. 2013. Pembelajaran Kontekstual Untuk Meningkatkan kemampuan Representasi Matematis Siswa sekolah Menengah Pertama. Infinity Jurnal Ilmiah Program Studi Matematika STKIP Siliwangi Bandung. Vol. 2 No. 1. Hal: 85-99.

[22] Zakaria,. Chung, L. C dan Yusuf, D. M. 2010. The Effects of Cooperative Learning on Students' Mathematics Achievement and Attitude towards Mathematics. Journal of Social Sciences. Vol. 6. No. 2. Hal: 272-275.

[23] Gagatsis, A. Panoura, A. Dan Elia, I. 2009. Students' Beliefs About The Use Of Representations In The Learning Of Fractions University of Cyprus: Federick University.

[24] Arcat. 2013. Meningkatkan Kemampuan Spasial dan Self Efficacy Siswa SMP Melalui Model Kooperatif STAD Berbantuan Wingeom. Universitas Pendidikan Indonesia : Bandung.

[25] Kemendikbud. 2013. Peraturan Menteri Pendidikan Nasional Republik Indonesia Nomor 65 Tahun 2013 Tentang Standar Isi untuk Satuan Pendidikan Dasar dan Menengah. Jakarta: Depdiknas.

[26] Kemendikbud. 2013. Peraturan Menteri Pendidikan Nasional Republik Indonesia Nomor 81A Tahun 2013 Tentang Implementasi Kurikulum Pedoman Umum Pembelajaran. Jakarta: Kementerian Pendidikan dan Kebudayaan.

[27] Wasriono, Syahputra, E dan Surya, E. 2015. Pengembangan Perangkat Pembelajaran Berbantuan Autograph Untuk Meningkatkan Pemahaman Konsep Matematik Siswa SMK Melalui Model Penemuan Terbimbing, Jurnal Paradikma, Vol. 8 No.3. Hal:52-61.

[28] Surya, E dan Syahputra, E. 2017. Improving High-Level Thinking Skills by Develpment of Learning PBL Approach on The Learning
Mathematics for senior High School Students. International Education Studies. Vol.10. No.8. Hal: 12-20.

[29] Juliana, M., dan Surya, E. (2015). An Analysis Of Jingsaw Cooperative Effectiveness To Improve The Self-Confidance And Learning Result Of Vocation High School Student's. IJARIIE. Vol. 3-Issue-2.

[30] Yuniara, P., Surya, E. (2017). Application of Problem Based Learning to Students' Improving on Mathematics Concept of Ability. IJSBAR. Vol. 3, No. 33, pp 261-269.

[31] Cahyo, A. 2013. Panduan Apikasi Teori-Teori Belajar Mengajar Teraktual dan Terpopuler. Yogyakarta: DIVA Press.

[32] Ergin, I., Kanli, U dan Unsal, Y. (2008). An example for the effect of the $5 \mathrm{E}$ model on the academic success and attitude levels of students: Inclined projectile motion. Journal of Turkish Science Education. Vol:5 no. 3. Hal: 47-59.

[33] Rosalina, Natalia. R, Sutawidjaja. A, Sudirman. 2016 Pengembangan Perangkat Pembelajaran Berbasis Model Learning Cycle-7e pada Materi Trigonometri untuk Meningkatkan Kemampuan Koneksi Matematis Siswa. Jurnal Pendidikan: Teori, Penelitian, dan Pengembangan. Vol. 1 No. 6. Hal: 1042-1055.

[34] Baharuddin dan Wahyuni, N,. 2007. Teori Belajar dan Pembelajaran. Yogyakarta: Ar-Ruzz Media Group.

[35] Tran, T. 2014. Discovery learning with the Help Of Geogebra Dynamic Geometry Software. International Journal of Learning, Teaching and Educational Research Vol.7. No.1. pp. 44-57.

[36] Adhar, E. L. 2012. Pembelajaran Matematika dengan metode penemuan terbimbing untuk meningkatkan kemampuan representasi dan pemecahan masalah matematis siswa SMP. Jurnal Penelitian Pendidikan. Vol. 13. No. 2. Hal: 1-10.

[37] Casad. 2012. Learning Through Guided Discovery: An Engaging Approach t0 K-12 STEM Education. American Society for Engineering Education. Ac 2012-3665

[38] Adelia, W.S. dan Surya, E. 2017. Resolution to Increase Capacity by using Math Students Learning Guided Discovery Learning (gdl). International Journal of Sciences: Basic and Applied Research (IJSBAR). Volume. 34, No. 1

[39] Silalahi,J.A. 2015. Pengaruh Model Pembelajaran Learning Cycle terhadap kemampuan berpikir kritis matematika siswa pada materi pokok bahasan balok di Kelas VIII SMP NEGERI 2 TANJUNG MORAWA T.A 2014/2015. Skripsi. Program Studi Pendidikan Matematika, Fakultas Keguruan dan Ilmu Pendidikan, Universitas HKBP Nommensen Medan.

[40] Nurul, F. H., Johar, R., Ikhsan, M. 2016. Peningkatan Kemampuan Spasial dan Self-efficacy Siswa Melalui Model Discovery Learning Berbasis Multimedia. Beta. Vol. 9 No. 2. Hal. 180-196.

[41] Shirley, L. 1995. Using Ethnomathematics to find Multicultural Mathematical Connection: NCTM.

[42] Rizka, S., Mastur Z., dan Rochmad. 2014. Model Project Based Learning Bermuatan Etnomatematika untuk Meningkatkan Kemampuan Koneksi Matematika. Unnes Journal of Mathematics Education Research. Vol. 3. No. 2. Hal: 73-78.

[43] Abdullah, A.A. 2016. Peran Guru Dalam Mentransformasi Pembelajaran Matematika Berbasis Budaya. Prosiding Seminar Matematika dan Pendidikan Matematika.Hal 640-652. 